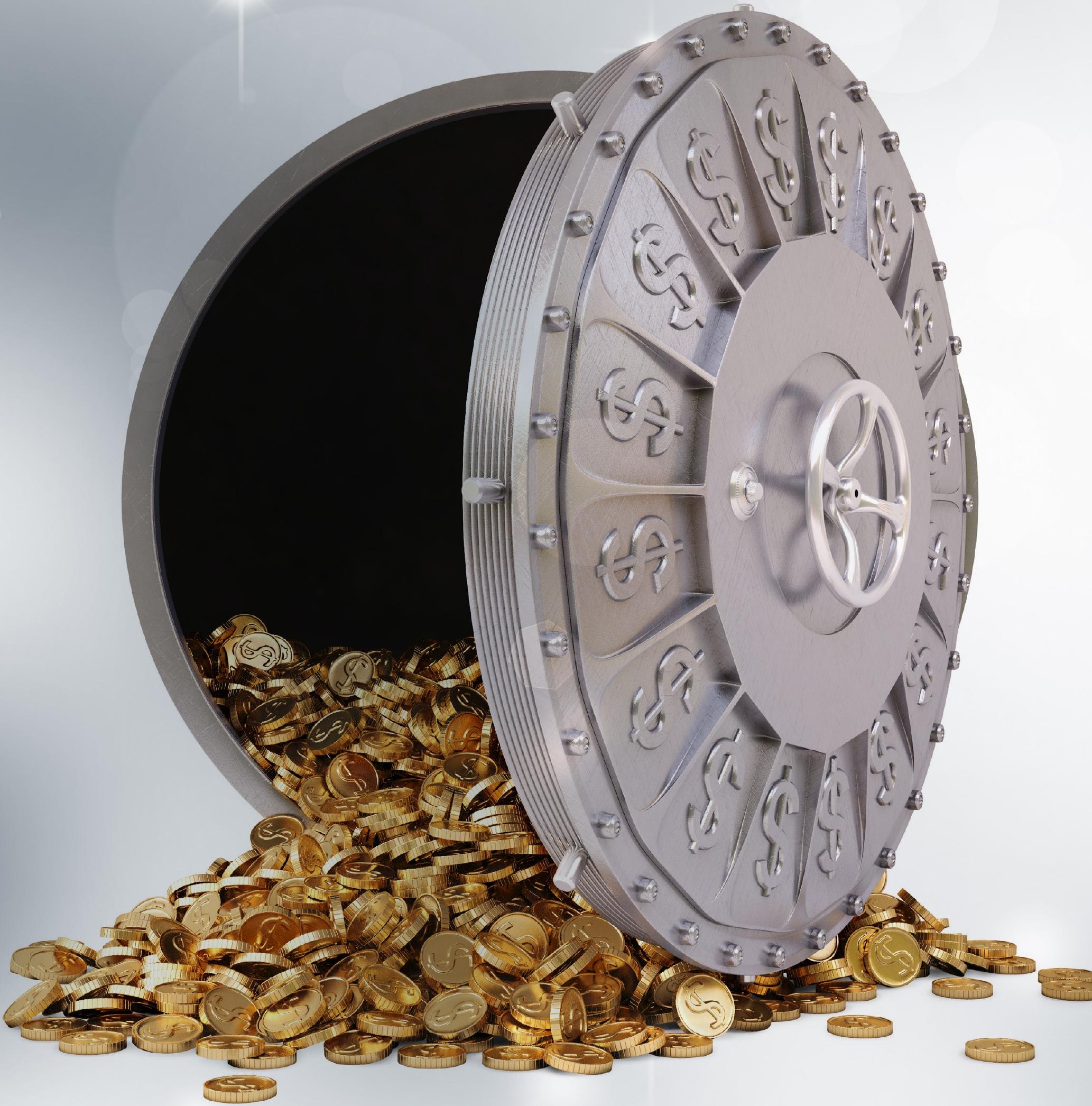




\section{NOVOS RISCOS E OPORTUNIDADES}

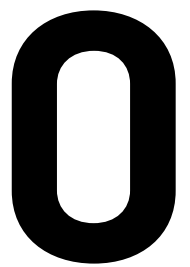

caderno especial deste número é dedicado às finanças. Quatro forças estão transformando a área financeira: a digitalização da economia, a sofisticação nas análises de dados, a administração de novos riscos - estratégicos, regulatórios, cibernéticos e de reputação - e a pressão intensa dos stakeholders. Como argumenta Antonio José Rocha de Almeida, autor do artigo $O$ líder financeiro sob pressão desta edição, trabalhar com finanças, hoje, inclui responsabilidades estratégicas. $\mathrm{O}$ que faz um grande chief financial officer (CFO)? Ele ou ela precisa gerenciar a crescente volatilidade dos negócios.

Assim, neste número trazemos artigos que mostram como essas mudanças estão afetando desde a gestão financeira e contábil das empresas até os negócios emergentes, passando por multinacionais, bancos, fundos de investimento e de private equity e instituições de microcrédito. Nos artigos selecionados, Hsia Hua Sheng e José Marcos Carrera Junior defendem que as multinacionais brasileiras precisam diminuir sua dependência de recursos estatais e buscar novas estratégias globais. Sobre a disrupção digital, Lauro Gonzalez destaca como tecnologias em ascensão permitem modelos inovadores para o microcrédito no Brasil, enquanto Rafael Schiozer e Orlando Vilar apontam alternativas tecnológicas para aumentar o volume de empréstimos no país. Edilene Santana Santos revela como a adoção de um padrão internacional único em contabilidade tem melhorado a qualidade das informações financeiras das empresas no Brasil. Dois artigos discutem fundos de investimento: Cláudio Vilar Furtado e Giovane Spagnuolo Belluzzo mostram as transformações na indústria de private equity e venture capital, e Pedro Luiz Albertin Bono Milan e William Eid Júnior apresentam a evolução dos fundos de investimento no país. Jimmy Greer descortina os modelos de negócios do futuro.

Vale ressaltar que vários autores desta edição participam ativamente de Centros de Estudos da FGV EAESP nessas áreas, e os trabalhos aqui expostos resultam de pesquisas aplicadas com alto potencial de impacto na gestão das empresas.

Além disso, trazemos uma entrevista absolutamente importante nesse momento do país: Oded Grajew, fundador de ONGS como Rede Nossa São Paulo, Fundação Abrinq pelos Direitos da Criança e do Adolescente e Instituto Ethos, discute suas ideias sobre ética e corrupção nas empresas.

Completam este número as colunas de: Samy Dana, a respeito de convicções desastrosas para decisões financeiras; Tales Andreassi, sobre as dificuldades dos empreendedores em lidar com finanças; Priscila Miguel, que chama a atenção para o papel estratégico da gestão da cadeia de suprimentos; e Paulo Sandroni, que analisa o momento econômico e político atual.

Boa leitura!

Maria José Tonelli - Editora chefe

Adriana Wilner - Editora adjunta 